Check for updates

Cite this: RSC Adv., 2017, 7, 47695

Received 28th August 2017

Accepted 25th September 2017

DOI: $10.1039 / c 7 r a 09538 d$

rsc.li/rsc-advances

\section{Light induced construction of porous covalent organic polymeric networks for significant enhancement of $\mathrm{CO}_{2}$ gas sorption $\dagger$}

\author{
Soumitra Bhowmik, Maruthi Konda and Apurba K. Das (iD *
}

\begin{abstract}
Herein, we report morphology-controlled porous polymeric materials for enhanced $\mathrm{CO}_{2}$ capture, which was achieved using the topochemical polymerization of dipeptide functionalized diphenylbutadiynes. The topochemical reaction was executed to control the morphology of the synthesized dipeptide appended diarylbutadiyne derivatives on a solid surface. Topochemical polymerization involves the formation of polydiacetylene due to the presence of hydrogen bonding between the amide groups and intermolecular $\pi-\pi$ stacking interactions in their self-assembled state, which was established using UV-Vis, Raman and IR spectroscopy. The change in morphology of the two dipeptide functionalized diphenylbutadiyne (DPB) was confirmed by scanning electron microscopy. Porosity was developed after UV irradiation of the diacetylene-based dipeptide appended bolaamphiphiles. Interestingly, after UV irradiation, the porous covalent organic polymers 1 and 2 show 24.22 times and 12 times enhanced $\mathrm{N}_{2}$ gas adsorption than their parent compounds 1 and 2, respectively. The surface area of the porous covalent organic polymers 1 and 2 was enhanced 21.68 times and 5.54 times than their parent compounds 1 and 2, respectively. Polymer 1 exhibits 4.23 times the $\mathrm{CO}_{2}$ capture ability than compound 1 and polymer 2 shows 4.1 times the $\mathrm{CO}_{2}$ capture ability than compound 2. This study highlights the controlled synthesis of light induced porous covalent organic polymers with high surface area used for efficient $\mathrm{CO}_{2}$ storage applications.
\end{abstract}

\section{Introduction}

In recent years, an enormous amount of greenhouse gases including $\mathrm{CO}_{2}$ are released into the atmosphere with the earth's increasing population, which has triggered a rapid increase in atmospheric temperature..$^{1-5}$ Inspired by natural zeolite structures, researchers are working to develop porous materials for effective $\mathrm{CO}_{2}$ capture. Porous materials, such as covalent organic polymers (COPs), ${ }^{6-11}$ metal-organic frameworks $(\mathrm{MOFs})^{12}$ and covalent organic frameworks $(\mathrm{COFs})^{13,14}$ with miscellaneous properties and applications have attracted great attention in materials science research. Porous covalent polymers are used as effective $\mathrm{CO}_{2}$ sorption materials due to their ultra-high hydrothermal stability. Porous COPs are potentially beneficial for gas storage and separation, ${ }^{15}$ catalysis, ${ }^{16}$ chemical sensing, drug delivery, ${ }^{17}$ electronic devices ${ }^{18}$ and energy storage applications. ${ }^{19}$ However, considerable attention has been focused on controlling the self-assembly, pore size, surface area and functionality in nanoporous solids. Precise molecular self-assembly enables the arrangement of molecules in

Department of Chemistry, Indian Institute of Technology Indore, Indore 453552, India. E-mail: apurba.das@iiti.ac.in

$\dagger$ Electronic supplementary information (ESI) available: Synthesis details, spectroscopic data for all synthesized compounds, SEM image, TGA data and gas adsorption data. See DOI: 10.1039/c7ra09538d a well-defined molecular architecture with specific shape and size. The controlled self-assembly of peptide-based amphiphiles has attracted great attention due to their unique architectures, including fibers, ${ }^{20-24}$ tubes, ${ }^{25-27}$ spheres, ${ }^{28-31}$ vesicles $^{32-35}$ and cylinders ${ }^{36-38}$ as well as their applications in drug delivery ${ }^{39,40}$ and injectable therapy to control hemorrhage. ${ }^{41}$ Peptide-based bolaamphiphiles are a unique class of amphiphiles, which can self-assemble into different architectures through noncovalent interactions upon the influence of external stimuli. ${ }^{42-45}$ Upon incorporation of a diacetylene moiety into the peptide backbones, peptide functionalized diacetylene-based amphiphiles can self-assemble into an oriented fashion and form self-assembled nanostructures. Peptide-functionalized diphenylbutadiyne-based bolaamphiphiles can also be polymerized using topochemical polymerization if they are appropriately oriented. Peptide-functionalized polydiacetylene-based amphiphiles have been used in several applications such as chromatic sensors, lipopolysaccharide detectors, biotechnology and biomedicine. ${ }^{46-48}$ Peptide-functionalized polydiacetylenebased amphiphilic fibers have also been used to sense cell adhesion via its colorimetric sensing behaviour upon UV irradiation. ${ }^{49}$ Its self-organization behaviour also changes with a change in suitable spacer length in the case of diacetylenecontaining peptide bolaamphiphiles..$^{50}$ Diacetylene containing peptide bolaamphiphiles have also been used as optoelectronic materials. $^{51}$ The conducting poly(diphenylbutadiyne) 


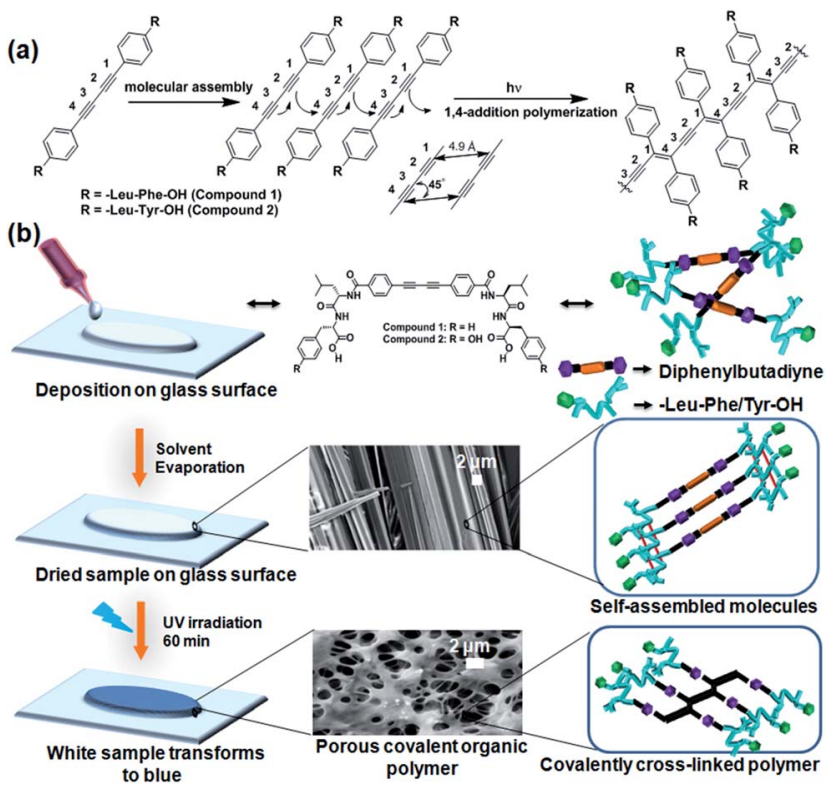

Fig. 1 (a) Typical topochemical polymerization mechanism. (b) Schematic representation of the preparation method used for compound 1 on a glass substrate for photochemical reaction in the solid state for $1 \mathrm{~h}$.

nanostructures synthesized via photochemical polymerization show high photocatalytic activity for the photodecomposition of phenol and methyl orange under visible-light irradiation. ${ }^{\mathbf{2}}$ Inspired by the diverse self-assembly nature of peptide bolaamphiphiles, ${ }^{53-59}$ we demonstrate the topochemical polymerization of two dipeptide appended diphenylbutadiynes on a solid surface that exhibit different morphologies.

In this regard, we have synthesized two dipeptide appended diphenylbutadiynes-based bolaamphiphiles, HO-Phe-Leu-DPBLeu-Phe-OH (compound 1) and HO-Tyr-Leu-DPB-Leu-Tyr-OH (compound 2) (DPB = diphenylbutadiyne, $\mathrm{Phe}=$ phenylalanine, Leu = leucine, Tyr = tyrosine), to examine their morphological patterns before and after UV irradiation (Fig. 1). The self-organization of the dipeptide appended poly (diphenylbutadiyne)s was controlled based on the dipeptidesequence and concentration of the bolaamphiphile. The morphological alternations of the two compounds under UV irradiation have been studied using SEM. This study corresponds to a step forward in the design of porous polymer network structures from fibrillar structures. ${ }^{60}$ The porous polymeric network structures adsorbed $\mathrm{CO}_{2}$ gas almost four times higher than the fibrillar network structures of self-assembled molecules. Thus, the rational design of light induced diacetylene-based porous covalent organic polymers has a prominent impact on $\mathrm{CO}_{2}$ adsorption.

\section{Experimental section}

\section{Materials}

Methyl 4-iodo benzoate, trimethylsilylacetylene (TMSA), tetramethylethylenediamine (TMEDA), CuCl (copper(I) chloride), CuI (copper(I) iodide) and $\mathrm{Pd}\left(\mathrm{PPh}_{3}\right)_{2} \mathrm{Cl}_{2}$ (bis(triphenylphosphine)
palladium(II) dichloride) were purchased from Alfa Aesar, India. L-Leucine, L-phenylalanine, L-tyrosine, HOBt (1-hydroxybenzotriazole) and DCC ( $N, N^{\prime}$-dicyclohexylcarbodiimide) were obtained commercially. For the chemical reactions and purification of the peptides, methanol, dimethylformamide (DMF), ethyl acetate and hexane were dried according to the reported literature procedures. The reactions were monitored by thin-layer chromatography (TLC). All the intermediates and final compounds were purified and characterized using NMR (400 MHz) and mass spectroscopy.

\section{General}

Mass spectrometry was performed on a Bruker MicrOTOF-Q II by positive-mode electrospray ionization. All NMR spectra were recorded on a Bruker AV $400 \mathrm{MHz}$ spectrometer at $298 \mathrm{~K}$. The PL spectra of the films $\left(C=20 \mathrm{mmol} \mathrm{\textrm {L } ^ { - 1 }}\right)$ were measured on a Horiba ScientificFluoromax-4 spectrophotometer. The FT-IR spectra of all the reported compounds were performed using a Bruker (Tensor-27) FT-IR spectrophotometer. A Raman study was performed on a Micro Raman system from Jobin Yvon Horiba LABRAM-HR visible (400-1100 nm) equipped with an $\mathrm{Ar}^{+}$laser (488 nm, $10 \mathrm{~mW}$ ) excitation source and CCD detector.

\section{Synthesis of compounds}

Synthesis of methyl 4-((trimethylsilyl)ethynyl)benzoate 6 . Methyl 4-iodobenzoate (9 g, $34.35 \mathrm{mmol}), \quad\left[\mathrm{PdCl}_{2}\left(\mathrm{PPh}_{3}\right)_{2}\right]$ (1.203 g, $1.71 \mathrm{mmol})$, CuI (0.0654 g, $0.3435 \mathrm{mmol})$ and $\mathrm{Et}_{3} \mathrm{~N}$ (40 $\mathrm{mL}$ ) were added to a two-necked round bottom flask equipped with a condenser and magnetic stirrer and supplied with an inert atmosphere (Scheme S1, ESI $\dagger$ ). The mixture was purged with Ar flow for $30 \mathrm{~min}$ and then trimethylsilylacetylene (1.686 $\mathrm{g}, 17.175 \mathrm{mmol}$ ) was added. The reaction mixture was slowly heated up to $80{ }^{\circ} \mathrm{C}$ and stirred for $12 \mathrm{~h}$. After cooling to room temperature, the reaction mixture was filtered to remove any insoluble materials and the solid was washed with $\mathrm{CH}_{2} \mathrm{Cl}_{2}$. The filtrates were combined and concentrated under reduced pressure to afford a yellow-orange residue, which was extracted with $\mathrm{CH}_{2} \mathrm{Cl}_{2}(3 \times 50 \mathrm{~mL})$. The organic layer was washed twice with $\mathrm{H}_{2} \mathrm{O}$ and dried over $\left(\mathrm{Na}_{2} \mathrm{SO}_{4}\right)$, and evaporated under vacuum to yield 6. Purification was carried out using silica gel column chromatography (100-200 mesh) using DCM and hexane $(0.1$ : 9.9) as the eluent to obtain 6 (7.5 g, $32.32 \mathrm{mmol}$, $94 \%$ ) as a yellow powder. ${ }^{1} \mathrm{H}-\mathrm{NMR}\left(400 \mathrm{MHz}, \mathrm{CDCl}_{3}\right): \delta 7.98$ (d, $2 \mathrm{H}, J=8 \mathrm{~Hz}$ ), 7.53 (d, $2 \mathrm{H}, J=8 \mathrm{~Hz}$ ), 3.91 (s, $\left.3 \mathrm{H}, \mathrm{OCH}_{3}\right), 0.26$ (s, 9H) ppm. $\left.{ }^{13} \mathrm{C} \mathrm{NMR} \mathrm{(100} \mathrm{MHz,} \mathrm{CDCl}_{3}\right): \delta 166.4,131.8,129.6$, 129.3, 127.7, 104.0, 97.6, 52.1 ppm.

Synthesis of methyl 4-ethynylbenzoate 7. Methyl 4-((trimethylsilyl)ethynyl)benzoate $(7.48 \mathrm{~g}, 32.164 \mathrm{mmol})$ was stirred in methanol $(40 \mathrm{~mL})$ and potassium carbonate $(8.874 \mathrm{~g}, 64.328 \mathrm{mmol})$ was added. The mixture was stirred for $90 \mathrm{~min}$. The progress of the reaction was monitored by thin layer chromatography (TLC). After completion of the reaction, the solvent was removed under vacuum. $1 \mathrm{~N} \mathrm{HCl}(30 \mathrm{~mL})$ was slowly added and the product was extracted with dichloromethane. The collected DCM extract was dried over $\mathrm{Na}_{2} \mathrm{SO}_{4}$ and concentrated under vacuum to yield 7 as a white solid. Purification was carried out 
using silica gel column chromatography (100-200 mesh) using DCM and hexane $(0.1: 9.9)$ as the eluent to obtain $7(2.624 \mathrm{~g}$, $16.4 \mathrm{mmol}, 51 \%)$ as a white powder. ${ }^{1} \mathrm{H}-\mathrm{NMR}\left(\mathrm{CDCl}_{3}, 400 \mathrm{MHz}\right)$ : $\delta 7.94(\mathrm{~d}, 2 \mathrm{H}, J=8 \mathrm{~Hz}$, aromatic $\mathrm{H}), 7.49(\mathrm{~d}, 2 \mathrm{H}, J=8 \mathrm{~Hz}$, aromatic $\mathrm{H}), 3.85\left(\mathrm{~s}, 3 \mathrm{H}, \mathrm{OCH}_{3}\right), 3.16(\mathrm{~s}$, acetylene $\mathrm{H}) \mathrm{ppm} .{ }^{13} \mathrm{C}$ NMR (100 MHz, $\left.\mathrm{CDCl}_{3}\right): \delta 166.3,131.9,130.0,129.3,126.6,82.7$, 79.9, $52.1 \mathrm{ppm}$.

Synthesis of 1,4-bis( $p$-carbomethoxybenzene)-1,3-butadiyne 8. Methyl 4-ethynylbenzoate 7 (2.5 g, $15.624 \mathrm{mmol})$ was dissolved in acetone $(40 \mathrm{~mL})$. Copper(I) chloride $(33.07 \mathrm{mg}, 0.328 \mathrm{mmol})$ and TMEDA (58.53 mg, $0.494 \mathrm{mmol}$ ) were added and the mixture was stirred under open air conditions for $1 \mathrm{~d}$. The precipitate was filtered and washed with acetone $(1 \times 25 \mathrm{~mL})$ and then washed with chloroform $(1 \times 25 \mathrm{~mL})$ and the solvent was removed by rotary evaporation to give crude $\mathbf{8}$. Purification was carried out using silica gel column chromatography (100-200 mesh) using toluene as the eluent to obtain $8(2.04 \mathrm{~g}, 6.41 \mathrm{mmol}, 41.1 \%)$ as a white solid. ${ }^{1} \mathrm{H}-\mathrm{NMR}\left(\mathrm{CDCl}_{3}, 400 \mathrm{MHz}\right): \delta 8.01(\mathrm{~d}, 4 \mathrm{H}, J=$ $8.4 \mathrm{~Hz}$ ), 7.59 (d, $4 \mathrm{H}, J=8.4 \mathrm{~Hz}), 3.93$ (s, 6H, $\mathrm{CH}_{3}$ ) ppm. ${ }^{13} \mathrm{C} \mathrm{NMR}$ $\left(\mathrm{CDCl}_{3}, 100 \mathrm{MHz}\right) \delta 166.35,132.59,130.66,129.69,126.22,81.99$, 76.39, 52.49 ppm. ESI-MS: calcd for $\left[\mathrm{C}_{20} \mathrm{H}_{14} \mathrm{O}_{4}+\mathrm{Na}\right]^{+}$341.0892, found 341.1.

Synthesis of 4,4'-(buta-1,3-diyne-1,4-diyl)dibenzoic acid 9. 1,4-Bis( $p$-carbomethoxybenzene)-1,3-butadiyne (1.9 g, 5.966 $\mathrm{mmol}$ ) and $\mathrm{NaOH}(2.386 \mathrm{~g}, 59.66 \mathrm{mmol})$ were dissolved in a mixture of THF $(25 \mathrm{~mL})$ and $\mathrm{H}_{2} \mathrm{O}(25 \mathrm{~mL})$. The solution was stirred at room temperature overnight. The $\mathrm{pH}$ of the solution was then adjusted to $\mathrm{pH} 2$ with $1 \mathrm{~N} \mathrm{HCl}$ solution. A precipitate was formed, which was collected by filtration, washed with $\mathrm{H}_{2} \mathrm{O}$ and dried in air to afford $9(1.186 \mathrm{~g}, 4.089 \mathrm{mmol}, 69 \%)$ as a white solid, which was used for the next step without further purification. The product exhibited low solubility in DMSO- $d_{6}$ for NMR characterization; triethylamine was added to the NMR sample to improve the solubility of 9. ${ }^{1} \mathrm{H}-\mathrm{NMR}$ (DMSO- $d_{6}, 400$ $\mathrm{MHz}): \delta 7.96(\mathrm{~d}, 4 \mathrm{H}, J=8 \mathrm{~Hz}), 7.6(\mathrm{~d}, 4 \mathrm{H}, J=8.0 \mathrm{~Hz}, 4 \mathrm{H}) \mathrm{ppm}$. ${ }^{13} \mathrm{C} \mathrm{NMR}\left(\mathrm{CDCl}_{3}, 100 \mathrm{MHz}\right): \delta 168.87,139.65,131.63,129.27$, 121.29, 82.19, 74.19 ppm.

\section{General procedure for peptide coupling}

Compound 9 (1.0 equiv.) was dissolved in dry DMF $\left(4 \mathrm{~mL} \mathrm{~g}^{-1}\right)$ and stirred on an ice-water bath (Schemes S2 and S3, ESI $\dagger$ ). The methyl ester protected amino acid was isolated from its corresponding methyl ester hydrochloride (4.0 equiv.) by neutralization and subsequently extracted twice with ethyl acetate $(2 \times 30 \mathrm{~mL})$. The collected ethyl acetate extracts were dried over anhydrous $\mathrm{Na}_{2} \mathrm{SO}_{4}$ and concentrated to $5 \mathrm{~mL}$. The solution was then added to the pre-cooled reaction mixture followed by the addition of HOBt (2.0 equiv.) and dicyclohexylcarbodiimide (DCC) (2.2 equiv.). The reaction mixture was stirred overnight. The residue was extracted by ethyl acetate $(50 \mathrm{~mL})$ and the DCU was removed by filtration. The organic layer was washed with $1 \mathrm{M}$ $\mathrm{HCl}(3 \times 50 \mathrm{~mL})$, brine $(2 \times 50 \mathrm{~mL}), 1 \mathrm{M}$ sodium carbonate $(3 \times 50 \mathrm{~mL})$, brine $(2 \times 50 \mathrm{~mL})$, dried over anhydrous $\mathrm{Na}_{2} \mathrm{SO}_{4}$ and evaporated in vacuum. Purification was carried out using silica gel column chromatography (100-200 mesh) using hexane-ethyl acetate $(9: 1)$ as the eluent to obtain the desired product.

\section{General procedure for methyl ester hydrolysis}

Methyl ester in $10 \mathrm{~mL}$ of $\mathrm{MeOH}$ was added to a round bottom flask and $2 \mathrm{~N} \mathrm{NaOH}$ was added drop-wise (Schemes 22 and S3, ESI $\dagger$ ). The reaction was monitored by thin layer chromatography (TLC). The reaction mixture was stirred overnight. $15 \mathrm{~mL}$ of distilled water was added to the reaction mixture and the $\mathrm{MeOH}$ was removed under vacuum. The aqueous part was washed with diethyl ether $(2 \times 30 \mathrm{~mL})$, then cooled in an ice-water bath for $10 \mathrm{~min}$ and the $\mathrm{pH}$ was adjusted to 2 upon the dropwise addition of $1 \mathrm{~N} \mathrm{HCl}$. It was extracted with ethyl acetate $(3 \times 50 \mathrm{~mL})$ and then the ethyl acetate layer was dried over anhydrous $\mathrm{Na}_{2} \mathrm{SO}_{4}$ and evaporated under vacuum to yield the corresponding carboxylic acid, which was used for the next step without any further purification.

Synthesis of MeO-Leu-DPB-Leu-OMe 10. Compound 10 was obtained as a white solid (1.2 g, $2.2 \mathrm{mmol}, 64 \%) .{ }^{1} \mathrm{H}-\mathrm{NMR}(400$ $\left.\mathrm{MHz}, \mathrm{CDCl}_{3}\right): \delta 7.79(\mathrm{~d}, 2 \mathrm{H}, J=8 \mathrm{H}$, aromatic $\mathrm{Hs}), 7.61(\mathrm{~d}, 2 \mathrm{H}, J=$ $8 \mathrm{~Hz}$, aromatic Hs), 6.58 (d, $2 \mathrm{H}, J=8 \mathrm{~Hz}, \mathrm{NH}$ of Leu), 4.86 (d, $2 \mathrm{H}$, $J=8 \mathrm{~Hz}, \mathrm{C}^{\alpha} \mathrm{Hs}$ of Leu), $3.78\left(\mathrm{~s}, 6 \mathrm{H}, \mathrm{OCH}_{3}\right), 1.95\left(\mathrm{~m}, 2 \mathrm{H}, \mathrm{C}^{\beta} \mathrm{Hs}\right.$ of Leu), 1.37 (m, 2H, C ${ }^{\beta}$ Hs of Leu), 1.16 (m, 2H, $\mathrm{C}^{\gamma} \mathrm{Hs}$ of Leu), 1.00 $\left(\mathrm{m}, 12 \mathrm{H}, \mathrm{C}^{\delta} \mathrm{Hs}\right.$ of Leu) ppm. ${ }^{13} \mathrm{C} \mathrm{NMR}\left(100 \mathrm{MHz}, \mathrm{CDCl}_{3}\right)$ : $\delta$ 173.26, 166.77, 132.40, 126.87, 81.28, 75.58, 52.51, 50.90, 41.59, 33.62, 25.28, 24.68, 24.60, 22.48, 21.77 ppm. ESI-MS: calcd for $\left[\mathrm{C}_{32} \mathrm{H}_{36} \mathrm{~N}_{2} \mathrm{O}_{6}+\mathrm{Na}\right]^{+}$567.2538, found 567.2455.

Synthesis of HO-Leu-DPB-Leu-OH 11. Compound 11 was obtained as a white solid (897 mg, $1.73 \mathrm{mmol}, 95 \%) .{ }^{1} \mathrm{H}-\mathrm{NMR}$ (400 MHz, DMSO- $d_{6}$ ): $\delta 8.69$ (d, $2 \mathrm{H}, J=8 \mathrm{~Hz}, \mathrm{NH}$ of Leu), 7.88 (d, $4 \mathrm{H}, J=8 \mathrm{~Hz}$, aromatic $\mathrm{Hs}), 7.68(\mathrm{~d}, 4 \mathrm{H}, J=8 \mathrm{~Hz}$, aromatic $\mathrm{Hs}), 4.38\left(\mathrm{~m}, 2 \mathrm{H}, \mathrm{C}^{\alpha} \mathrm{Hs}\right.$ of Leu), $1.7\left(\mathrm{~m}, 4 \mathrm{H}, \mathrm{C}^{\beta} \mathrm{Hs}\right.$ of Leu), 1.55 (m, 2H, $\mathrm{C}^{\gamma} \mathrm{Hs}$ of Leu), $0.87\left(\mathrm{~m}, 12 \mathrm{H}, \mathrm{C}^{\delta} \mathrm{Hs}\right.$ of Leu) ppm. ${ }^{13} \mathrm{C} \mathrm{NMR}$ (100 MHz, DMSO- $\left.d_{6}\right): \delta 174.36,167.87,134.30,130.77,80.18$, 76.58, 53.51, 51.70, 43.39, 35.55, 26.28, 23.50, 22.60, 21.70 ppm. ESI-MS: calcd for $\left[\mathrm{C}_{30} \mathrm{H}_{32} \mathrm{~N}_{2} \mathrm{O}_{6}+\mathrm{Na}\right]^{+} 539.2158$, found 539.2088.

Synthesis of MeO-Phe-Leu-DPB-Leu-Phe-OMe 12. Compound $\mathbf{1 2}$ was obtained as a white solid $(393 \mathrm{mg}$, $0.46 \mathrm{mmol}, 64 \%) .{ }^{1} \mathrm{H}-\mathrm{NMR}\left(400 \mathrm{MHz}, \mathrm{CDCl}_{3}\right): \delta 8.2(\mathrm{~d}, 1 \mathrm{H}, J=$ $8 \mathrm{~Hz}, \mathrm{NH}$ of Leu), 7.73 (d, 1H, $J=8 \mathrm{~Hz}$, NH of Leu), 7.67 (d, 1H, $=8 \mathrm{~Hz}, \mathrm{NH}$ of Phe), 7.57 (d, $1 \mathrm{H}, J=8 \mathrm{~Hz}$, NH of Phe), 7.42-6.32 (m, $18 \mathrm{Hs}$ of aromatic ring), $4.84\left(\mathrm{~m}, 2 \mathrm{H}, \mathrm{C}^{\alpha} \mathrm{Hs}\right.$ of Phe), $4.45(\mathrm{~m}$, $2 \mathrm{H}, \mathrm{C}^{\alpha} \mathrm{Hs}$ of Leu), $3.15\left(\mathrm{~m}, 2 \mathrm{H}, \mathrm{C}^{\beta} \mathrm{Hs}\right.$ of Phe), $3.05\left(\mathrm{~m}, 2 \mathrm{H}, \mathrm{C}^{\beta} \mathrm{Hs}\right.$ of Phe), 1.7 (m, 4H, $\mathrm{C}^{\beta} \mathrm{Hs}$ of Leu), 1.24 (m, 2H, $\mathrm{C}^{\gamma} \mathrm{Hs}$ of Leu), 0.91 (m, $12 \mathrm{H}, \mathrm{C}^{\delta} \mathrm{Hs}$ of Leu) ppm. ${ }^{13} \mathrm{C} \mathrm{NMR}\left(100 \mathrm{MHz}, \mathrm{CDCl}_{3}\right)$ : $\delta$ 171.47, 157.00, 129.56, 128.90, 127.46, 60.70, 53.43, 52.63, 48.47, 38.16, 34.26, 26.24, 25.24, 25.03, 23.50, 21.36, 14.50 ppm. ESI-MS: calcd for $\left[\mathrm{C}_{50} \mathrm{H}_{54} \mathrm{~N}_{4} \mathrm{O}_{8}+\mathrm{Na}\right]^{+}$861.3839; found 861.3786.

Synthesis of HO-Phe-Leu-DPB-Leu-Phe-OH 1. Compound 1 was obtained as a white solid (346 $\mathrm{mg}, 0.427 \mathrm{mmol}, 95 \%)$. FT-IR $\left(\mathrm{KBr}, \nu, \mathrm{cm}^{-1}\right): \mathrm{N}-\mathrm{H} 3272(\mathrm{~N}-\mathrm{H}$, amide $\mathrm{A}), 1734(\mathrm{C}=\mathrm{O}$, free carboxylic), 1649 ( $\mathrm{C}=\mathrm{O}$, amide I), 1541 ( $\mathrm{N}-\mathrm{H}$, amide II). ${ }^{1} \mathrm{H}$ NMR (400 MHz, DMSO- $d_{6}$ ): $\delta 12.68$ (s, 2H, COOH), 8.51 (d, $2 \mathrm{H}, J=8 \mathrm{~Hz}, \mathrm{NH}), 8.14$ (d, 2H, $J=8 \mathrm{~Hz}, \mathrm{NH}), 7.89$ (d, 2H, $J=$ $8 \mathrm{~Hz}$, aromatic $\mathrm{H}), 7.59(\mathrm{~d}, 2 \mathrm{H}, J=8 \mathrm{~Hz}$, aromatic $\mathrm{Hs}), 7.22(\mathrm{~m}$, $10 \mathrm{H}$ of Phe aromatic ring), $4.57\left(\mathrm{~m}, 2 \mathrm{H}, \mathrm{C}^{\alpha} \mathrm{Hs}\right.$ of Phe), $4.46(\mathrm{~m}$, $2 \mathrm{H}, \mathrm{C}^{\alpha} \mathrm{Hs}$ of Leu), $3.05\left(\mathrm{~m}, 2 \mathrm{H}, \mathrm{C}^{\beta} \mathrm{Hs}\right.$ of Phe), $2.94\left(\mathrm{~m}, 2 \mathrm{H}, \mathrm{C}^{\beta} \mathrm{Hs}\right.$ of Phe), 1.67 (m, $4 \mathrm{H}, \mathrm{C}^{\beta} \mathrm{Hs}$ of Leu), 1.51 (m, $2 \mathrm{H}, \mathrm{C}^{\gamma} \mathrm{Hs}$ of Leu), $0.90\left(\mathrm{~m}, 12 \mathrm{H}, \mathrm{C}^{\delta} \mathrm{Hs}\right.$ of Leu) ppm. ${ }^{13} \mathrm{C}$ NMR (100 MHz, DMSO- $\left.d_{6}\right)$ : 
$\delta 177.95,177.19,170.64,142.67,139.40,136.75,134.37,133.33$, 131.60, 129.71, 88.14, 88.04, 58.53, 56.84, 41.77, 29.55, 28.26, 26.66 ppm. ESI-MS: calcd for $\left[\mathrm{C}_{48} \mathrm{H}_{50} \mathrm{~N}_{4} \mathrm{O}_{8}+\mathrm{Na}\right]^{+}$833.3526, found 833.3264.

Synthesis of MeO-Tyr-Leu-DPB-Leu-Tyr-OMe 13. Compound 13 was obtained as a white solid (600 mg, $0.688 \mathrm{mmol}, 89.6 \%$ ). ${ }^{1} \mathrm{H}-\mathrm{NMR}\left(400 \mathrm{MHz}, \mathrm{DMSO}-d_{6}\right): \delta 9.26(\mathrm{~s}, 2 \mathrm{H}$, phenolic $\mathrm{OH}$ of Tyr), 8.50 (d, 2H, $J=8 \mathrm{~Hz}, \mathrm{NH}), 8.25$ (d, $2 \mathrm{H}, J=8 \mathrm{~Hz}, \mathrm{NH}), 7.87$ $(\mathrm{d}, 2 \mathrm{H}, J=8 \mathrm{~Hz}$, aromatic $\mathrm{H}), 7.57(\mathrm{~d}, 2 \mathrm{H}, J=8 \mathrm{~Hz}$, aromatic $\mathrm{H})$, $6.98(\mathrm{~d}, 4 \mathrm{H}, J=8 \mathrm{~Hz}, 4 \mathrm{H}$ of Tyr aromatic ring), 6.61 (d, $4 \mathrm{H}, J=$ $8 \mathrm{~Hz}, 4 \mathrm{H}$ of Tyr aromatic ring), 4.38 (d, $2 \mathrm{H}, J=8 \mathrm{~Hz}, \mathrm{C}^{\alpha} \mathrm{Hs}$ of Leu), 3.55 (s, $6 \mathrm{H}$ of $\left.\mathrm{COOCH}_{3}\right), 3.05\left(\mathrm{~m}, 2 \mathrm{H}, \mathrm{C}^{\beta} \mathrm{Hs}\right.$ of Phe), 2.88 (m, 2H, $\mathrm{C}^{\beta} \mathrm{H}$ of Tyr), $1.62\left(\mathrm{~m}, 4 \mathrm{H}, \mathrm{C}^{\beta} \mathrm{Hs}\right.$ of Leu), $1.25(\mathrm{~m}, 2 \mathrm{H}$, $\mathrm{C}^{\gamma} \mathrm{Hs}$ of Leu), $0.89\left(\mathrm{~m}, 12 \mathrm{H}, \mathrm{C}^{\delta} \mathrm{Hs}\right.$ of Leu) ppm. ${ }^{13} \mathrm{C}$ NMR $(100$ MHz, DMSO- $\left.d_{6}\right): \delta 199.15,192.93,184.26,140.56,137.87$, $134.37,133.33,130.30,128.66,115.97,115.50$, 94.92, 91.84, 41.17, 33.94, 24.92, 22.79, 131.60, 129.71, 88.14, 88.04, 58.53, $56.84,41.77,29.55,28.26,26.66 \mathrm{ppm}$. ESI-MS: calcd for $\left[\mathrm{C}_{50} \mathrm{H}_{54} \mathrm{~N}_{4} \mathrm{O}_{10}+\mathrm{Na}\right]^{+}$893.3840, found 893.3960.

Synthesis of HO-Tyr-Leu-DPB-Leu-Tyr-OH 2. Compound 2 was obtained as a white solid (456 mg, $0.541 \mathrm{mmol}, 95 \%)$. FT-IR $\left(\mathrm{KBr}, \nu, \mathrm{cm}^{-1}\right): 3284(\mathrm{~N}-\mathrm{H}$, amide $\mathrm{A}), 1761(\mathrm{C}=\mathrm{O}$, free carboxylic), 1621 ( $\mathrm{C}=\mathrm{O}$, amide I), $1536\left(\mathrm{~N}-\mathrm{H}\right.$, amide II). ${ }^{1} \mathrm{H}$-NMR $(400$ MHz, DMSO- $d_{6}$ ): $\delta 12.62(\mathrm{~m}, 2 \mathrm{H}, \mathrm{COOH}), 9.18$ (s, 2H, phenolic$\mathrm{OH}$ of Tyr), 8.52 (d, 2H, $J=8 \mathrm{~Hz}, \mathrm{NH}$ of Tyr), 8.03 (d, 2H, $J=$ $8 \mathrm{~Hz}, \mathrm{NH}$ ), 7.88 (d, $2 \mathrm{H}, J=8 \mathrm{~Hz}$, aromatic $\mathrm{Hs}$ ), 7.58 (d, $J=8 \mathrm{~Hz}$, $2 \mathrm{H}$, aromatic $\mathrm{Hs}), 7.00(\mathrm{~d}, 4 \mathrm{H}, J=8 \mathrm{~Hz}, 4 \mathrm{H}$ of Tyr aromatic ring), $6.61(\mathrm{~d}, 4 \mathrm{H}, J=8 \mathrm{~Hz}, 4 \mathrm{H}$ of Phe aromatic ring), 4.55 (d, $2 \mathrm{H}, J=$ $8 \mathrm{~Hz}, \mathrm{C}^{\alpha} \mathrm{Hs}$ of Tyr), 4.38 (d, 2H,J=8 Hz, C ${ }^{\alpha} \mathrm{Hs}$ of Leu), 2.94 (m, $2 \mathrm{H}, \mathrm{C}^{\beta} \mathrm{Hs}$ of Tyr), 2.91 (m, $2 \mathrm{H}, \mathrm{C}^{\beta} \mathrm{Hs}$ of Tyr), $1.52\left(\mathrm{~m}, 4 \mathrm{H}, \mathrm{C}^{\beta} \mathrm{Hs}\right.$ of Leu), $1.25\left(\mathrm{~m}, 2 \mathrm{H}, \mathrm{C}^{\gamma} \mathrm{Hs}\right.$ of Leu), $0.90\left(\mathrm{~m}, 12 \mathrm{H}, \mathrm{C}^{\delta} \mathrm{Hs}\right.$ of Leu) ppm. ${ }^{13} \mathrm{C}$ NMR (100 MHz, DMSO- $\left.d_{6}\right): \delta$ 178.06, 177.12, $170.70,161.12$, 139.43, 136.76, 135.29, 133.03, 132.61, 129.70, 120.15, 88.15, 88.06, 58.88, 56.84, 41.04, 29.57, 26.27, 26.64 ppm. ESI-MS: calcd for $\left[\mathrm{C}_{48} \mathrm{H}_{50} \mathrm{~N}_{4} \mathrm{O}_{10}+\mathrm{Na}\right]^{+}$865.3425, found 865.3583 .

\section{Sample preparation}

Compound solutions were prepared by mixing $16.2 \mathrm{mg}$ of compound 1 and $16.8 \mathrm{mg}$ of compound 2, individually in $1 \mathrm{~mL}$ of methanol in glass vials. The compounds were completely dissolved by shaking. Then, $1 \mathrm{~mL}$ of each of the as-prepared solutions was drop-casted on clean and dried glass slides and was allowed to dry in air at room temperature. Then, the films were irradiated using $254 \mathrm{~nm}$ UV light. SEM measurements were performed on the dried films after $60 \mathrm{~min}$ of UV irradiation by coating with gold for both compounds 1 and 2 . Field emission scanning electron microscopic study was performed on a Carl Zeiss microscope (model-Supra 55).

\section{Topochemical polymerization procedure}

Topochemical polymerization was accompanied on the films upon irradiation at $254 \mathrm{~nm}$ using a $72 \mathrm{~W}$ UV lamp at $25{ }^{\circ} \mathrm{C}$. For these experiments, the dried thin films of the compounds were irradiated for $1 \mathrm{~h}$. A condenser was attached to the reactor to maintain its temperature at about $25{ }^{\circ} \mathrm{C}$.

\section{DFT calculations}

DFT calculations were performed using Gaussian 09 to evaluate the role of the dipeptide side chains in the transformation of morphology during topochemical polymerization. DFT calculations employing the B3LYP functional were carried out on monomer and short oligomers of the conjugated organic polymer. For efficient calculation, we simplified the molecular structure using a polydiacetylene chain without the peptide side chain. A long dipeptide side chain creates overlapping of the orbitals leading to steric strain. To avoid such problems, we carried out the DFT calculation of the conjugated organic polymer without considering the peptide side chain.

\section{Thermogravimetric analysis (TGA)}

Thermogravimetric analysis (TGA) was performed using a METTLER TOLEDO TGA instrument. The samples were heated from 25 to $600{ }^{\circ} \mathrm{C}$ at a constant rate of $5{ }^{\circ} \mathrm{C} \mathrm{min}{ }^{-1}$ under a nitrogen atmosphere.

\section{Gas sorption measurement}

Gas $\left(\mathrm{N}_{2} / \mathrm{CO}_{2}\right)$ adsorption/desorption experiments were carried out using a Quantachrome Autosorb IQ2 Automated Gas Sorption System at $77 \mathrm{~K}\left(\mathrm{~N}_{2}\right.$ sorption experiments) and $298 \mathrm{~K}\left(\mathrm{CO}_{2}\right.$ sorption experiments) over the pressure range between 0.025 bar and 1 bar (40 points system). Before the sorption measurements, monomer $\mathbf{1}$, polymer $\mathbf{1}$, monomer 2 and polymer 2 were degassed for $10 \mathrm{~h}$ with a heating rate of $5{ }^{\circ} \mathrm{C} \mathrm{min}^{-1}$. From the gas adsorption results at low $P / P_{0}$, the pore size distribution of the samples was calculated using the BJH (Barrett-Joyner-Halenda analysis) method. The BET surface area was calculated from the Brunauer-Emmett-Teller (BET) equation.

\section{Results and discussion}

\section{Topochemical polymerization on solid surface}

Dipeptide appended diphenylbutadiyne-based bolaamphiphiles (compounds 1 and $2, C=20 \mathrm{mmol} \mathrm{L}^{-1}$ ) were suspended in methanol for dissolution (Fig. 1). Compound 1 in methanol and a two-day aged methanol solution of compound 2 were then drop-casted on quartz glass to prepare their films. Compounds $\mathbf{1}$ and $\mathbf{2}$ based films were allowed to polymerize under UV light irradiation ( $72 \mathrm{~W}, 254 \mathrm{~nm})$. A film based on compound 1 turned blue whereas the film based on compound 2 turned yellow after $60 \mathrm{~min}$ of UV irradiation. As a result of an effective regioselective 1,4-polymerization of the self-organized compound $\mathbf{1}$, blue colour was observed. UV-Vis spectra were collected to understand the variation in the absorption spectra of the bolaamphiphiles on solid surfaces after the topochemical polymerization reaction (Fig. 2). Prior to UV irradiation, compound 1 absorbed at $340 \mathrm{~nm}$. A new peak appeared in the visible-light region at $610 \mathrm{~nm}$ (Fig. 2a) after polymerization. The new peak at $610 \mathrm{~nm}$ appeared due to the formation of polydiacetylene (the film turned to blue after $60 \mathrm{~min}$ of UV irradiation for compound 1). ${ }^{61,62}$ Similarly, the UV-Vis spectra of compound 2 were recorded (Fig. 2b) before and after UV 

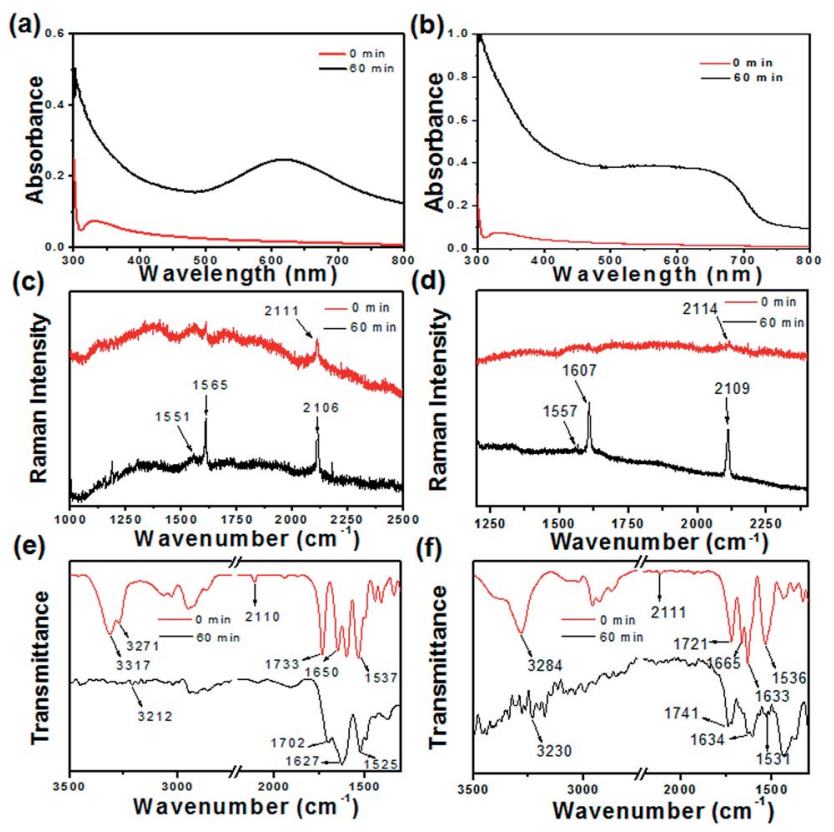

Fig. 2 UV-Vis spectra of (a) compound 1 and (b) compound 2 before and after UV polymerization. Raman spectra of (c) compound 1 and (d) compound 2 before and after 60 min of topochemical polymerization. FTIR spectra of (e) compound 1 and (f) compound 2 before (red line) and after 60 min (black line) of topochemical polymerization.

irradiation. Compound 2 absorbed a peak at $334 \mathrm{~nm}$ prior to UV irradiation, which was attributed to the $\pi-\pi^{*}$ transition of diphenylbutadiyne. After 60 min of UV irradiation, a new broad peak appeared at $658 \mathrm{~nm}$ and the film turned to yellow.

Fourier-transform Raman spectroscopy (FT-Raman) and FTIR spectroscopy were used to monitor the polymerization reaction of compounds 1 and 2 on the solid surface (Fig. 2). Before UV irradiation, the Raman spectrum of compound 1 shows a peak at $2111 \mathrm{~cm}^{-1}$, which is assigned to the regular stretching mode of 1,3-butadiyne. After UV irradiation, the characteristic peak at $2111 \mathrm{~cm}^{-1}$ disappears and a new peak appears at $2106 \mathrm{~cm}^{-1}$ after $60 \mathrm{~min}$ of the polymerization reaction. The peak at $2106 \mathrm{~cm}^{-1}$ arises due to the presence of a $\mathrm{C} \equiv \mathrm{C}$ bond within the conjugated polymer after UV irradiation. A new peak at $1565 \mathrm{~cm}^{-1}$ appears after UV irradiation due to the formation of $\mathrm{C}=\mathrm{C}$ bonds. It has been reported that the characteristic peaks between 1400 and $1600 \mathrm{~cm}^{-1}$ appear due to the stretching vibration of enyne (Fig. 2c). ${ }^{63}$ Compound 2 shows a characteristic peak at $2114 \mathrm{~cm}^{-1}$, which is attributed to the presence of the $\mathrm{C} \equiv \mathrm{C}$ stretching vibration. However, the $\mathrm{C} \equiv \mathrm{C}$ stretching vibration peak shifted to $2109 \mathrm{~cm}^{-1}$ after $1 \mathrm{~h}$ of UV irradiation. A new peak appears at $1607 \mathrm{~cm}^{-1}$ after UV irradiation of compound 2 due to the formation of $\mathrm{C}=\mathrm{C}$ bonds (Fig. 2d). ${ }^{63,64}$ These results indicate that both compounds were transformed into poly(diphenylbutadiyne) upon UV irradiation. Fig. 2e and $\mathrm{f}$ show the FT-IR spectra of compounds 1 and 2 prior and after the UV polymerization reaction. As shown in Fig. 2e, the characteristic peaks at 3317 and $3271 \mathrm{~cm}^{-1}$ for amide $\mathrm{N}-\mathrm{H}$ stretching, $1650 \mathrm{~cm}^{-1}$ for amide I and $1537 \mathrm{~cm}^{-1}$ for amide II band were observed. Weak peaks in the region of
3100-3500 $\mathrm{cm}^{-1}$ were observed after the topochemical polymerization reaction, which are indicative of the formation of weakly hydrogen bonded $\mathrm{NH}$ groups. However, a sharp peak at $2110 \mathrm{~cm}^{-1}$ appeared due to the presence of $\mathrm{C} \equiv \mathrm{C}$ in compound 1. The intensity of the corresponding $\mathrm{C} \equiv \mathrm{C}$ peak decreases after UV irradiation. After topochemical polymerization, the amide I band at $1650 \mathrm{~cm}^{-1}$ was shifted to $1627 \mathrm{~cm}^{-1}$. The FT-IR results evidently support the structural changes during the polymerization reaction occurring after UV irradiation. ${ }^{65,66}$ The FT-IR spectra were also acquired for compound 2 before and after the topochemical polymerization reaction. Fig. $2 \mathrm{f}$ shows the FTIR spectra for compound 2. The FT-IR peaks at $3284 \mathrm{~cm}^{-1}$ for amide $\mathrm{N}-\mathrm{H}$ stretching, $1665 \mathrm{~cm}^{-1}$ and $1633 \mathrm{~cm}^{-1}$ for amide I and $1536 \mathrm{~cm}^{-1}$ for amide II are observed prior to the photochemical polymerization reaction of compound 2 . Low intense peaks in the region of $3100-3500 \mathrm{~cm}^{-1}$ were observed after the topochemical polymerization, which are indicative of the formation of weakly hydrogen-bonded NH groups. These results suggest that intermolecular hydrogen bonding between the $\mathrm{N}-\mathrm{H}$ and $\mathrm{C}=\mathrm{O}$ of the amide groups drives the formation of the self-assembled fiber architecture prior to UV polymerization. The self-organized structures were formed due to the polymerization of compounds $\mathbf{1}$ and $\mathbf{2}$ induced by UV irradiation.

The change in morphology of the two compounds under UV polymerization was studied using scanning electron microscopy (SEM) (Fig. 3). Compound 1, after dissolution in methanol, was drop-casted onto quartz glass slides and revealed fibers (Fig. 3a). After $60 \mathrm{~min}$ of UV irradiation, the morphology alters to a porous network structure (Fig. 3b). The entire experiment was performed with a $20 \mathrm{mmol} \mathrm{L}^{-1}$ solution of compound 1 . The experiments were performed in triplicate and similar results were obtained. Similar experiments were performed with $15 \mathrm{mmol} \mathrm{L}^{-1}$ and $30 \mathrm{mmol} \mathrm{L}^{-1}$ solutions of compound 1 . Different types of morphological changes were observed with respect to the duration of $\mathrm{UV}$ irradiation for $15 \mathrm{mmol} \mathrm{L}^{-1}$ and $30 \mathrm{mmol} \mathrm{L}^{-1}$ solutions of compound 1 (Fig. S1 and S2, ESI $\dagger$ ). Here, the self-organized structures of compound $\mathbf{1}$ change into polymerized porous network structures upon topochemical polymerization with different morphological features. The topochemical polymerization of compound $\mathbf{2}$ was also performed on the solid surface and in the solid state (Fig. S3, ESI $\dagger$ ). Compound $2\left(20 \mathrm{mmol} \mathrm{L}^{-1}\right)$ was dissolved in methanol. Instant deposition of the methanolic solution of compound 2 did not form a selfassembled structure. However, the two-day aged solution of compound 2 forms fibrillar morphology (Fig. S3a, ESI $\dagger$ ).

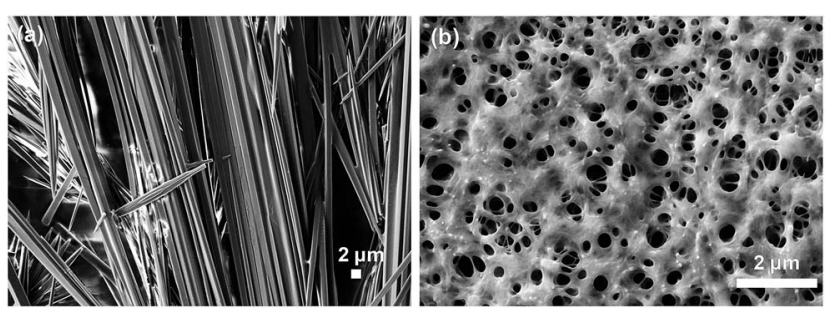

Fig. 3 SEM images at different times of the UV reaction of compound 1: (a) before the UV reaction and (b) after 60 min of UV irradiation (polymer 1). 
The fibrillar morphology obtained for the two compounds $\mathbf{1}$ and 2 are relatively different. This differential morphology was observed probably due to the presence of the polar phenolic $-\mathrm{OH}$ group present in the tyrosine containing compound 2 . Due to the presence of the phenolic $-\mathrm{OH}$ group, compound 2 exhibits a more hydrophilic nature when compared with the hydrophobic phenylalanine-based compound 1 . The different lattice packing features also drive the discrepancy of the typical fibrous morphological properties in a particular solvent. ${ }^{67}$ After $60 \mathrm{~min}$ of UV irradiation, compound 2 shows a porous network structure (Fig. S3b, ESI $\dagger$ ). Here, UV polymerization changes the morphology and self-organization of compound $\mathbf{1}$ and compound 2 on a solid surface. ${ }^{68}$ For both the compounds, the hydrogen bonding and $\pi-\pi$ interactions between the molecules are involved in the formation of the self-assembled fibers. The dipeptide appended diphenylbutadiyne-based molecules are linear due to the presence of the two conjugated triple bonds. Due to an increase in degree of polymerization, the polymers become aggregated and the morphology changes after $1 \mathrm{~h}$ of UV irradiation (Scheme 1). After UV irradiation, the hydrogen bonds involved in the dipeptides become weaker. After 60 min of UV irradiation, the fibers are re-organized to form a porous network structure. This was evidenced in the FT-IR spectra with the peak intensity of the NH stretching of the amide bonds between 3000$3300 \mathrm{~cm}^{-1}$ decreasing after $1 \mathrm{~h}$ of UV irradiation. At this time, the formation of polydiacetylene was also evidenced by Raman spectroscopy as new peaks corresponding to the formation of enyne developed between $1400-1600 \mathrm{~cm}^{-1} \cdot{ }^{69,70}$ Intermolecular hydrogen bonding becomes weaker and the formation of polymeric enyne is responsible for the structural changes observed for compound 1. Similarly, compound 2 shows the fibrillar morphology prior to UV irradiation due to the linear configuration in the presence of the two conjugated triple bonds. After $1 \mathrm{~h}$ of UV irradiation, the hydrogen bonds become weaker as evidenced by the FTIR spectra. The fibrillar structures turn into polymerized porous networks with an alternating ene-yne configuration. From the DFT study, we have observed that after the topochemical polymerization reaction, steric crowding between peptide side chains disrupts the hydrogen bonding. Due to disruption of the hydrogen bonding, the fibrillar morphology transforms to a porous network morphology. The closest distance between the two molecules due to the formation of the diyne was $3.6 \AA$. This result supports the crystal structure of a reported diyne system. ${ }^{71}$ The distance between the two peptide molecules should be 4.7 A. ${ }^{72}$ Hence, the hydrogen bonds between the amide groups in the peptide molecules are disrupted. As a result, the fibrillar structures transform to porous network structures.

Thermogravimetric analysis (TGA) was performed to analyse the thermal stability of compound $\mathbf{1}$, polymer $\mathbf{1}$, compound 2 and polymer 2 (Fig. S4, ESI $\dagger$ ). The decomposition temperature of compounds 1 and 2 was observed between $150-200{ }^{\circ} \mathrm{C}$ with an initial weight loss of $2-6 \%$. However, the decomposition temperature of polymers $\mathbf{1}$ and $\mathbf{2}$ was observed between 500-600 ${ }^{\circ} \mathrm{C}$ with an initial weight loss of $2-6 \%$. Hence, the thermal stability of the polymers was higher than their corresponding monomeric compounds.

In current research, porous covalent organic polymers with high surface areas have gained particular interest in the area of greenhouse gas storage. ${ }^{73}$ To analyse their porous features, gas adsorption studies were executed with the dried self-assembled structures of compounds 1 and 2 grown from a methanol solution and the $60 \mathrm{~min}$ UV irradiated polymers of 1 and 2 . Polymer 1 exhibits 24.22 times more $\mathrm{N}_{2}$ gas uptake than compound 1 (Table 1). The BET (Brunauer-Emmett-Teller) surface area of compound 1 was calculated to be $4.905 \mathrm{~m}^{2} \mathrm{~g}^{-1}$ whereas the BET surface area becomes $106.38 \mathrm{~m}^{2} \mathrm{~g}^{-1}$ for polymer $\mathbf{1}$. Thus, the surface area of polymer $\mathbf{1}$ exhibits a 21.68 fold higher surface area than compound $\mathbf{1}$. The pore volume of compound 1 was calculated to be $0.0144 \mathrm{~cm}^{3} \mathrm{~g}^{-1}$, whereas the pore volume of polymer 1 was revealed to be $0.3845 \mathrm{~cm}^{3} \mathrm{~g}^{-1}$ (Fig. 4). The BET surface area of compound 2 was measured to be $10.599 \mathrm{~m}^{2} \mathrm{~g}^{-1}$, whereas the BET surface area becomes $58.800 \mathrm{~m}^{2} \mathrm{~g}^{-1}$ for polymer 2 . Thus, the surface area of polymer 2 was 5.54 times higher than the surface area of compound 2 . The pore volume of compound 2 was measured to be $0.0156 \mathrm{~cm}^{3} \mathrm{~g}^{-1}$ whereas the pore volume of polymer 2 was $0.1966 \mathrm{~cm}^{3} \mathrm{~g}^{-1}$. Interestingly, the porous polymer structures show enhanced sorption preferences than their corresponding monomers. ${ }^{74-77}$ The porosity developed on the surface after light induced polymerization of compounds $\mathbf{1}$ and $\mathbf{2}$ was in good agreement with the SEM images. According to the IUPAC

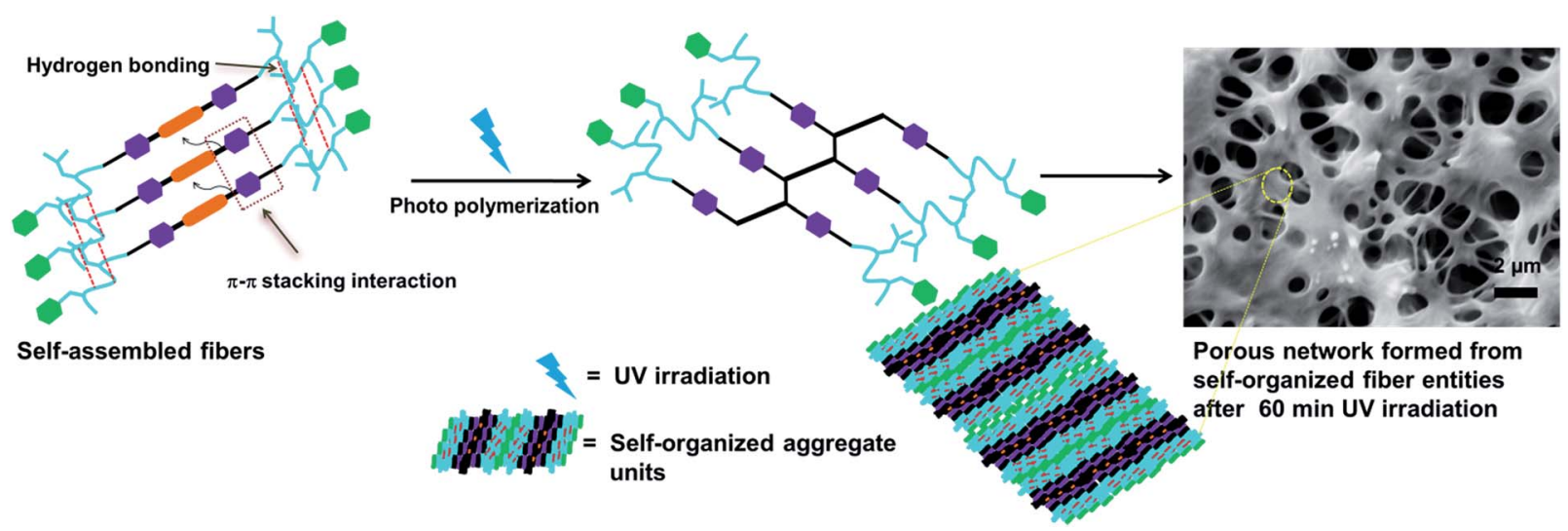

Scheme 1 Possible self-assembly mechanism of the dipeptide appended diphenylbutadiyne based compound 1. 
Table 1 BET surface properties and pore parameters of compound 1, polymer 1, compound 2 and polymer 2 obtained from the $\mathrm{N}_{2}$ and $\mathrm{CO}_{2}$ sorption studies

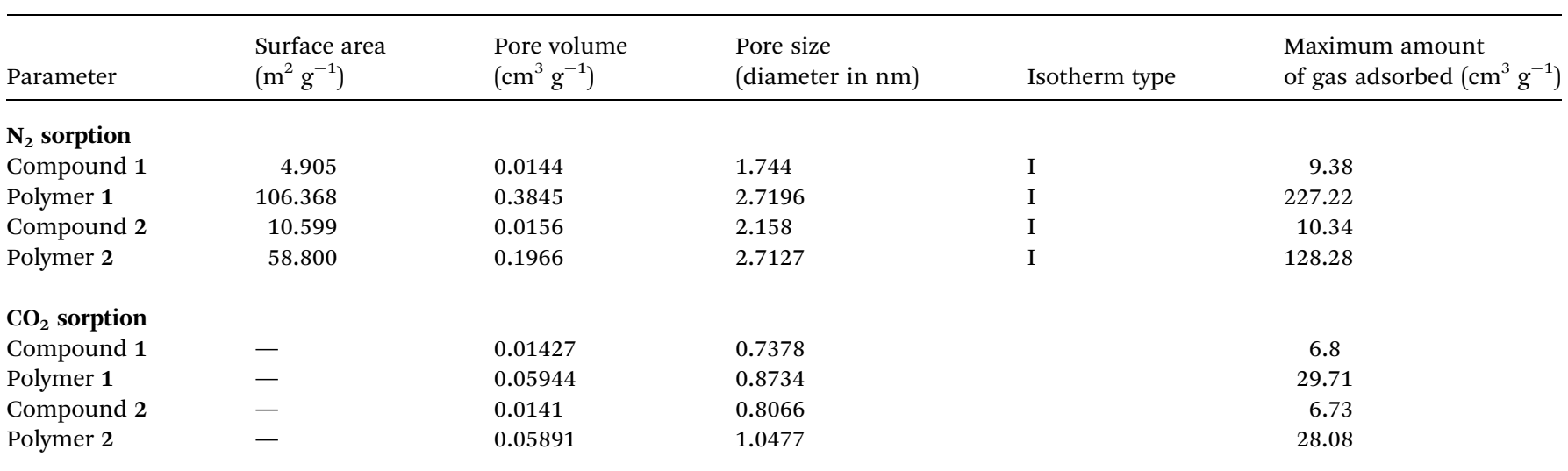

nomenclature, the $\mathrm{N}_{2}$ gas isotherms measured for compounds 1 and 2 , and polymers 1 and 2 can be classified by type I isotherms corresponding to a hierarchically porous material. As shown in Fig. 4c, the $\mathrm{CO}_{2}$ uptake of compound 1 was measured to be $6.8 \mathrm{~cm}^{3} \mathrm{~g}^{-1}$. However, the $\mathrm{CO}_{2}$ uptake was calculated to be $29.71 \mathrm{~cm}^{3} \mathrm{~g}^{-1}$ for polymer 1 . Thus, polymer 1 exhibits 4.36 times more $\mathrm{CO}_{2}$ storage capacity than compound 1 . The $\mathrm{CO}_{2}$ uptake of compound 2 was measured to be $6.73 \mathrm{~cm}^{3} \mathrm{~g}^{-1}$. However, the $\mathrm{CO}_{2}$ uptake observed for polymer 2 was measured to be $28.08 \mathrm{~cm}^{3} \mathrm{~g}^{-1}$ (Fig. 4d). Thus, polymer 2 shows 4.17 times more $\mathrm{CO}_{2}$ storage capacity than compound 2 (Table 1). The $\mathrm{CO}_{2}$ uptake capacities of the synthesized covalent organic polymers (1.32 $\mathrm{mmol} \mathrm{g}^{-1}$ for polymer 1 and $1.25 \mathrm{mmol} \mathrm{g}^{-1}$ for polymer 2 ) at 1 bar are comparable to the previously reported adsorption capacities of COPs and porous organic solids. Porous organic solids such as TCMP-3 and TCMP-0 adsorb $1.29 \mathrm{mmol} \mathrm{g}^{-1}$ and $1.34 \mathrm{mmol} \mathrm{g}^{-1} \mathrm{CO}_{2}$, respectively. Other COPs such as CMP-1 (1.18 mmol g $\left.{ }^{-1}\right)$, CMP-1-(COOH) $\left(0.95 \mathrm{mmol} \mathrm{g}^{-1}\right)$, CMP-1$\left(\mathrm{NH}_{2}\right)\left(0.95 \mathrm{mmol} \mathrm{g}^{-1}\right), \mathrm{CMP}-1\left(\mathrm{CH}_{3}\right)_{2}\left(0.94 \mathrm{mmol} \mathrm{g}^{-1}\right)$, CMP-1(OH) $\left(1.07 \mathrm{mmol} \mathrm{g}{ }^{-1}\right)$, CMP-5 (1.1 mmol g $\left.{ }^{-1}\right)$, CMP-5 (0.63 mmol g ${ }^{-1}$ ), PMF-1 (1.33 mmol g $\left.{ }^{-1}\right)$ and TCMP-5 $\left(0.681 \mathrm{mmol} \mathrm{g}^{-1}\right)$ also adsorb $\mathrm{CO}_{2} \cdot{ }^{78-82}$ In addition, the advantage of our as-prepared polymer-adsorbents is that they can be synthesized easily via a light-assisted polymerization reaction. Captivatingly, these polydiacetylene-adsorbents can capture $\mathrm{CO}_{2}$ gas in a significant amount. The development of the porous architectures with enhanced surface areas after topochemical polymerization was responsible for their enhanced $\mathrm{CO}_{2}$ sorption.

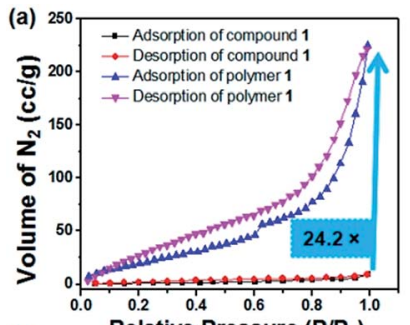

(c)

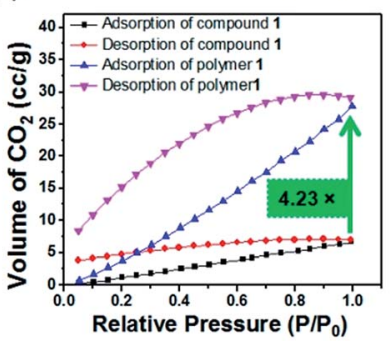

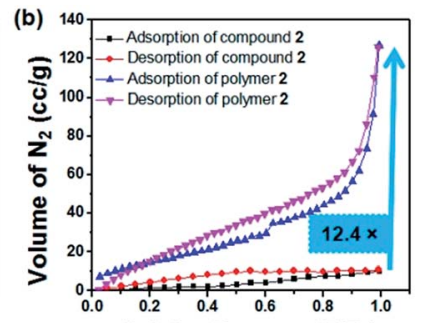

(d)

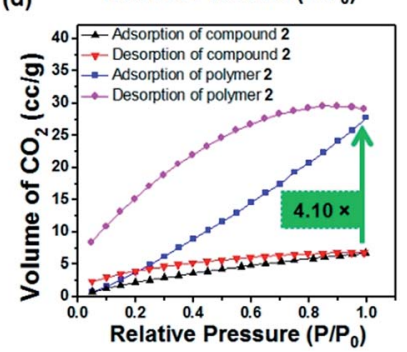

Fig. 4 (a) $\mathrm{N}_{2}$ adsorption and desorption isotherms at $77 \mathrm{~K}\left(P_{0}=1 \mathrm{~atm}\right)$ obtained for compound 1 and polymer 1 . (b) $\mathrm{N}_{2}$ adsorption and desorption isotherms at $77 \mathrm{~K}\left(P_{0}=1 \mathrm{~atm}\right)$ obtained for compound 2 and polymer 2. (c) $\mathrm{CO}_{2}$ adsorption and desorption isotherms at $298 \mathrm{~K}$ $\left(P_{0}=1 \mathrm{~atm}\right)$. (d) $\mathrm{CO}_{2}$ adsorption and desorption isotherms at $298 \mathrm{~K}$ $\left(P_{0}=1 \mathrm{~atm}\right)$ obtained for compound 2 and polymer 2 .

\section{Conclusion}

In summary, porous covalent organic polymers were developed using the topochemical polymerization of dipeptide appended diphenylbutadiyne-based bolaamphiphiles on a solid surface. Topochemical polymerization leads to change in the selforganized morphological features from fibers to porous network structures. The surface area, pore volume and porosity of the polymers were increased several times when compared to their corresponding compounds prior to polymerization. Polymers 1 and 2 exhibit 4.2 and 4.1 times more $\mathrm{CO}_{2}$ sorption behaviour than compounds 1 and 2, respectively. The porous polymer networks could interact with the $\mathrm{N}_{2}$ and $\mathrm{CO}_{2}$ gases through their amide bonds and the close proximity of the molecules through the covalent enyne bonds. The polymers are thermally stable when compared to their monomers, which was revealed by our TGA experiments. The light induced development of covalent organic polymers presented in this study unbolts new possibilities for tuning the porous properties of organic polymers for a variety of applications, including the design of catalysts and promising adsorbents for industrial applications. 


\section{Conflicts of interest}

There are no conflicts to declare.

\section{Acknowledgements}

AKD sincerely acknowledges NanoMission, Department of Science \& Technology (Project No. SR/NM/NS-1458/2014), New Delhi, India for financial support. SB is thankful to MHRD, New Delhi for his doctoral fellowship and MK is thankful to IIT Indore for his postdoctoral research fellowship. The sophisticated instrumentation centre (SIC), IIT Indore is acknowledged for providing access to their instrumentation. The authors thank the UGC-DAE Consortium for Scientific Research, Indore for their help in recording the Raman data.

\section{References}

1 R. Babarao and J. Jiang, Energy Environ. Sci., 2008, 1, 139143.

2 Z. Xiang, R. Mercado, J. M. Huck, H. Wang, Z. Guo, W. Wang, D. Cao, M. Haranczyk and B. Smit, J. Am. Chem. Soc., 2015, 137, 13301-13307.

3 S. De, J. Zhang, R. Luque and N. Yan, Energy Environ. Sci., 2016, 9, 3314-3347.

4 L. Zhai, N. Huang, H. Xu, Q. Chen and D. Jiang, Chem. Commun., 2017, 53, 4242-4245.

5 Z. Xiang and D. Cao, J. Mater. Chem. A, 2013, 1, 2691-2718. 6 Y.-L. Wong, J. M. Tobin, Z. Xu and F. Vilela, J. Mater. Chem. A, 2016, 4, 18677-18686.

7 K. Park, K. Lee, H. Kim, V. Ganesan, K. Cho, S. K. Jeong and S. Yoon, J. Mater. Chem. A, 2017, 5, 8576-8582.

8 G. Mukherjee, J. Thote, H. B. Aiyappa, S. Kandambeth, S. Banerjee, K. Vanka and R. Banerjee, Chem. Commun., 2017, 53, 4461-4464.

9 X. Shi, Y. Yao, Y. Xu, K. Liu, G. Zhu, L. Chi and G. Lu, ACS Appl. Mater. Interfaces, 2017, 9, 7481-7488.

10 Z. Xiang, X. Zhou, C. Zhou, S. Zhong, X. He, C. Qin and D. Cao, J. Mater. Chem., 2012, 22, 22663-22669.

11 G. Das, T. Prakasam, S. Nuryyeva, D. S. Han, A. Abdel-Wahab, J.-C. Olsen, K. Polychronopoulou, C. Platas-Iglesias, F. Ravaux, M. Jouiad and A. Trabolsi, J. Mater. Chem. A, 2016, 4, 15361-15369.

12 P. Ghosh, S. K. Saha, A. Roychowdhury and P. Banerjee, Eur. J. Inorg. Chem., 2015, 2015, 2851-2857.

13 P. Bhanja, K. Bhunia, S. K. Das, D. Pradhan, R. Kimura, Y. Hijikata, S. Irle and A. Bhaumik, ChemSusChem, 2017, 10, 921-929.

14 H. Ma, H. Ren, S. Meng, Z. Yan, H. Zhao, F. Sun and G. Zhu, Chem. Commun., 2013, 49, 9773-9775.

15 Z. Xiang, D. Cao, W. Wang, W. Yang, B. Han and J. Lu, J. Phys. Chem. C, 2012, 116, 5974-5980.

16 J. Sun and X. Bao, Chem.-Eur. J., 2008, 14, 7478-7488.

17 Q. Fang, J. Wang, S. Gu, R. B. Kaspar, Z. Zhuang, J. Zheng, H. Guo, S. Qiu and Y. Yan, J. Am. Chem. Soc., 2015, 137, 8352-8355.
18 S. Wan, J. Guo, J. Kim, H. Ihee and D. Jiang, Angew. Chem., Int. Ed., 2009, 48, 3207.

19 C. R. DeBlase, K. E. Silberstein, T.-T. Truong, H. D. Abruña and W. R. Dichtel, J. Am. Chem. Soc., 2013, 135, 16821-16824.

$20 \mathrm{~J}$. Hotz and W. Meier, Langmuir, 1998, 14, 1031-1036.

21 S. Lei, X. Gao, D. Cheng, L. Fei, W. Lu, J. Zhou, Y. Xiao, B. Cheng, Y. Wang and H. Huang, Eur. J. Inorg. Chem., 2017, 2017, 1892-1899.

22 A. Perino, M. Schmutz, S. Meunier, P. J. Mesini and A. Wagner, Langmuir, 2011, 27, 12149-12155.

23 N. Laggoune, F. Delattre, J. Lyskawa, F. Stoffelbach, J. M. Guigner, S. Ruellan, G. Cooke and P. Woisel, Polym. Chem., 2015, 6, 7389-7394.

24 V. V. Atuchin, T. A. Gavrilova, V. G. Kostrovsky, L. D. Pokrovsky and I. B. Troitskaia, Inorg. Mater., 2008, 44, 622.

25 A. D. Merg, J. C. Boatz, A. Mandal, G. Zhao, S. MokashiPunekar, C. Liu, X. Wang, P. Zhang, P. C. A. van der Wel and N. L. Rosi, J. Am. Chem. Soc., 2016, 138, 13655-13663.

26 L. Ziserman, H.-Y. Lee, S. R. Raghavan, A. Mor and D. Danino, J. Am. Chem. Soc., 2011, 133, 2511-2517.

27 F. J. M. Hoeben, P. Jonkheijm, E. W. Meijer and A. P. H. J. Schenning, Chem. Rev., 2005, 105, 1491-1546.

28 H. Choi, M. T. Jeena, L. Palanikumar, Y. Jeong, S. Park, E. Lee and J.-H. Ryu, Chem. Commun., 2016, 52, 5637-5640.

29 D. Mumcuoglu, M. Sardan Ekiz, G. Gunay, T. Tekinay, A. B. Tekinay and M. O. Guler, ACS Appl. Mater. Interfaces, 2016, 8, 11280-11287.

30 P. K. Sukul, P. Bose, T. Takei, O. M. Yaghi, Y. He, M. Lee and K. Tashiro, Chem. Commun., 2016, 52, 1579-1581.

31 X. Du, J. Zhou, J. Shi and B. Xu, Chem. Rev., 2015, 115, 1316513307.

32 C. Guo, Z. A. Arnon, R. Qi, Q. Zhang, L. Adler-Abramovich, E. Gazit and G. Wei, ACS Nano, 2016, 10, 8316-8324.

33 X. Yan, P. Zhu and J. Li, Chem. Soc. Rev., 2010, 39, 1877-1890. 34 N. Baccile, A.-S. Cuvier, S. Prévost, C. V. Stevens, E. Delbeke, J. Berton, W. Soetaert, I. N. A. Van Bogaert and S. Roelants, Langmuir, 2016, 32, 10881-10894.

35 E. Yashima, N. Ousaka, D. Taura, K. Shimomura, T. Ikai and K. Maeda, Chem. Rev., 2016, 116, 13752-13990.

36 D. Jiao, J. Geng, X. J. Loh, D. Das, T.-C. Lee and O. A. Scherman, Angew. Chem., Int. Ed., 2012, 51, 9633-9637.

37 T. Shimizu, N. Kameta, W. Ding and M. Masuda, Langmuir, 2016, 32, 12242-12264.

38 J. B. Matson, Y. Navon, R. Bitton and S. I. Stupp, ACS Macro Lett., 2015, 4, 43-47.

39 M. Liu, L. Zhang and T. Wang, Chem. Rev., 2015, 115, 73047397.

40 C. G. Palivan, R. Goers, A. Najer, X. Zhang, A. Car and W. Meier, Chem. Soc. Rev., 2016, 45, 377-411.

41 K. Ma, R. Xing, T. Jiao, G. Shen, C. Chen, J. Li and X. Yan, ACS Appl. Mater. Interfaces, 2016, 8, 30759-30767.

42 C. E. Morgan, A. W. Dombrowski, C. M. Rubert Pérez, E. S. M. Bahnson, N. D. Tsihlis, W. Jiang, Q. Jiang, J. M. Vercammen, V. S. Prakash, T. A. Pritts, S. I. Stupp and M. R. Kibbe, ACS Nano, 2016, 10, 899-909. 
43 A. C. Eldredge, M. E. Johnson, N. J. Oldenhuis and Z. Guan, Biomacromolecules, 2016, 17, 3138-3144.

44 S. Datta and S. Bhattacharya, Chem. Soc. Rev., 2015, 44, 55965637.

45 M. Konda, B. Kauffmann, D. B. Rasale and A. K. Das, Org. Biomol. Chem., 2016, 14, 4089-4102.

46 E. R. da Silva, M. N. M. Walter, M. Reza, V. Castelletto, J. Ruokolainen, C. J. Connon, W. A. Alves and I. W. Hamley, Biomacromolecules, 2015, 16, 3180-3190.

47 J. Jaworski, K. Yokoyama, C. Zueger, W.-J. Chung, S.-W. Lee and A. Majumdar, Langmuir, 2011, 27, 3180-3187.

48 J. J. Bang, K. K. Rupp, S. R. Russell, S. W. Choong and S. A. Claridge, J. Am. Chem. Soc., 2016, 138, 4448-4457.

49 S. Wang and K. S. Schanze, ACS Appl. Mater. Interfaces, 2013, 5, 4487.

50 B. E. I. Ramakers, S. A. Bode, A. R. Killaars, J. C. M. van Hest and D. W. P. M. Löwik, J. Mater. Chem. B, 2015, 3, 2954-2961.

51 K. Maeda, L. Hong, T. Nishihara, Y. Nakanishi, Y. Miyauchi, R. Kitaura, N. Ousaka, E. Yashima, H. Ito and K. Itami, J. Am. Chem. Soc., 2016, 138, 11001-11008.

52 M. Suzuki, J. F. K. Kotyk, S. I. Khan and Y. Rubin, J. Am. Chem. Soc., 2016, 138, 5939-5956.

53 S. Ghosh, N. A. Kouamé, L. Ramos, S. Remita, A. Dazzi, A. Deniset-Besseau, P. Beaunier, F. Goubard, P.-H. Aubert and H. Remita, Nat. Mater., 2015, 14, 505-511.

54 S. R. Diegelmann, N. Hartman, N. Markovic and J. D. Tovar, J. Am. Chem. Soc., 2012, 134, 2028-2031.

55 C. Tomasini and N. Castellucci, Chem. Soc. Rev., 2013, 42, 156-172.

56 I. Maity, D. B. Rasale and A. K. Das, Soft Matter, 2012, 8, 5301-5308.

57 I. Maity, H. S. Parmar, D. B. Rasale and A. K. Das, J. Mater. Chem. B, 2014, 2, 5272-5279.

58 A. K. Das, I. Maity, H. S. Parmar, T. O. McDonald and M. Konda, Biomacromolecules, 2015, 16, 1157-1168.

59 J. Kwak and S.-Y. Lee, ACS Appl. Mater. Interfaces, 2014, 6, 6461-6468.

60 I. W. Hamley, Angew. Chem., Int. Ed., 2014, 53, 6866-6881.

61 Q. Liu, S. Chen, J. Chen and J. Du, Macromolecules, 2015, 48, 739-749.

62 G. W. Coates, A. R. Dunn, L. M. Henling, D. A. Dougherty and R. H. Grubbs, Angew. Chem., Int. Ed. Engl., 1997, 36, 248-251.
63 L. Zhu, H. Tran, F. L. Beyer, S. D. Walck, X. Li, H. Ågren, K. L. Killops and L. M. Campos, J. Am. Chem. Soc., 2014, 136, 13381-13387.

64 J. R. Néabo, K. I. S. Tohoundjona and J.-F. Morin, Org. Lett., 2011, 13, 1358-1361.

65 A. Potisatityuenyong, R. Rojanathanes, G. Tumcharern and M. Sukwattanasinitt, Langmuir, 2008, 24, 4461-4463.

66 E. Jahnke, J. Weiss, S. Neuhaus, T. N. Hoheisel and H. Frauenrath, Chem.-Eur. J., 2009, 15, 388-404.

67 S. Biswas, D. B. Rasale and A. K. Das, RSC Adv., 2016, 6, 54793-54800.

68 M. Shirakawa, N. Fujita and S. Shinkai, J. Am. Chem. Soc., 2005, 127, 4164-4165.

69 K. Lv, L. Zhang and M. Liu, Langmuir, 2014, 30, 9295-9302.

70 J.-M. Kim, Y. B. Lee, S. K. Chae and D. J. Ahn, Adv. Funct. Mater., 2006, 16, 2103-2109.

71 J.-M. Heo, Y. Kim, S. Han, J. F. Joung, S. Lee, S. Han, J. Noh, J. Kim, S. Park, H. Lee, Y. M. Choi, Y.-S. Jung and J.-M. Kim, Macromolecules, 2017, 50, 900-913.

72 K. Morrisa and L. Serpel, Chem. Soc. Rev., 2010, 39, 34453453.

73 J. Li, D. Jia, Z. Guo, Y. Liu, Y. Lyu, Y. Zhou and J. Wang, Green Chem., 2017, 19, 2675-2686.

74 L. Wang, C. Pan, A. Liang, X. Zhou, W. Zhou, T. Wan and L. Wang, Polym. Chem., 2017, 8, 4644-4650.

75 K. Zhang, A. Nalaparaju and J. Jiang, J. Mater. Chem. A, 2015, 3, 16327-16336.

76 J. Hotz and W. Meier, Langmuir, 1998, 14, 1031-1036.

77 S.-L. Zhong, R. Xu, L.-F. Zhang, W.-G. Qu, G.-Q. Gao, X.-L. Wu and A.-W. Xu, J. Mater. Chem., 2011, 21, 16574-16580.

78 S. Ren, R. Dawson, A. Laybourn, J. Jiang, Y. Khimyak, D. J. Adams and A. I. Cooper, Polym. Chem., 2012, 3, 928-934.

79 S. K. Gupta, D. Kaleeswaran, S. Nandi, R. Vaidhyanathan and R. Murugavel, ACS Omega, 2017, 2, 3572-3582.

80 Y. Zeng, R. Zou and Y. Zhao, Adv. Mater., 2016, 28, 28552873.

81 A. Bhunia, V. Vasylyeva and C. Janiak, Chem. Commun., 2013, 49, 3961-3963.

82 Q. Xiao, J. Wen, Y. Guo, J. Hu, J. Wang, F. Zhang, G. Tu, Y. Zhong and W. Zhu, Ind. Eng. Chem. Res., 2016, 55, 12667-12674. 